Piotr Miazek

https://orcid.org/0000-0002-8372-122X

Uniwersytet Łódzki

Wydział Nauk Geograficznych

Instytut Gografii Miast i Turyzmu

piotr.miazek93@gmail.com

\title{
PRZYCZYNY ZRÓŻNICOWANIA RUCHU TURYSTYCZNEGO W POLSKICH PARKACH NARODOWYCH
}

\begin{abstract}
Abstrakt: Parki narodowe są jednymi z najczęściej odwiedzanych przez turystów miejsc w Polsce. Na ich obszarach koncentruje się blisko 30\% krajowego ruchu turystycznego. Corocznie przybywają tam miliony turystów, a ich liczba stale rośnie. Jednakże frekwencja w poszczególnych parkach narodowych jest mocno zróżnicowana. Jedne parki są odwiedzane przez miliony osób, inne zaś - zaledwie przez kilkanaście tysięcy turystów. Artykuł stanowi próbę wskazania głównych przyczyn zróżnicowania liczby turystów odwiedzających parki narodowe. Analizując poszczególne cechy ruchu turystycznego w konkretnych parkach narodowych, szczególnie w tych, w przypadku których różnice są najbardziej widoczne, autor starał się zidentyfikować czynniki wpływające na taki stan rzeczy.
\end{abstract}

Słowa kluczowe: ruch turystyczny, park narodowy, turystyka, różnice.

\section{WSTĘP}

Obszary chronione, $\mathrm{w}$ tym parki narodowe, przyciągają rzesze turystów, ze względu na niski stopień przekształcenia środowiska oraz wyjątkowe walory przyrodnicze i antropogeniczne. Na obszarach tych, z uwagi na ich specyfikę, możliwe jest uprawianie zróżnicowanych form turystyki i rekreacji. W początkowym okresie istnienia turystyki rejony cenne pod względem przyrodniczym stanowiły fundament rozwoju jej różnych rodzajów: wypoczynkowej, uzdrowiskowej, kwalifikowanej oraz krajoznawczej. W miarę upływu czasu i wraz z coraz intensywniejszym rozwojem zjawiska zwiększała się liczba osób, które odwiedzały obszary cenne przyrodniczo. W XIX w. osiągnęła ona taki poziom, że zaczęto zwracać uwagę na konieczność ochrony tych terenów. Idee ochrony przyrody zaczęły pojawiać się już w połowie XIX w. (Walas, 2019). Początkowo konieczność tych działań wymusiła antropopresja związana z przemysłem, transportem i rolnictwem. Jednak zwiększająca się liczba osób (badaczy, turystów, a także kolekcjonerów, kłusowników itp.) na terenach wartościowych pod względem przyrodniczym spowodowała, że zaczęto powoływać organizacje, które zajmowały się wspieraniem rozwoju turystyki oraz podejmowały działania na rzecz ochrony środowi- ska (np. założone w 1873 r. Towarzystwo Tatrzańskie). Wiek XX, a szczególnie okres po II wojnie światowej, to czas, kiedy turystyka na świecie przyjmuje charakter masowy. Mimo że instytucje ochrony przyrody zaczęły powstawać już w połowie XIX w., dopiero w drugiej połowie XX w. masowość turystyki znacząco wpłynęła na wyraźne przyspieszenie powoływania instytucji tego typu, również w Polsce. Pierwszy polski park narodowy utworzono w 1932 r., a przez następne pół wieku powstało ich 13. Obecnie w Polsce funkcjonują 23 parki narodowe, a 10 kolejnych (w tym m.in. Turnicki, Mazurski, Jurajski) jest projektowanych (Partyka, 2010a).

Mimo że powierzchnia wszystkich polskich parków narodowych zajmuje niewiele ponad $1 \%$ powierzchni całkowitej kraju, to ich unikatowość w porównaniu z innymi terenami powoduje, że są jednymi z najczęściej odwiedzanych przez turystów miejsc w Polsce. Z danych Głównego Urzędu Statystycznego (GUS) wynika, że w 2017 r. obszar polskich parków narodowych odwiedziło ponad 13 mln osób. W wielu parkach narodowych turystyka przyjmuje już charakter masowy, co $\mathrm{w}$ połączeniu z niskim poziomem edukacji turystów oraz zbyt małą świadomością ekologiczną może przynieść negatywne skutki. Dlatego też coraz 
większa liczba tych instytucji prowadzi edukację środowiskową i ekologiczną.

Problematyka ruchu turystycznego w parkach narodowych stanowi przedmiot wielu opracowań naukowych, a samo zagadnienie ruchu turystycznego prezentowane jest w różnych ujęciach. Liszewski (2009) oraz Partyka (2010a), charakteryzując ruch turystyczny, odwoływali się do obszarów wszystkich parków. Liszewski dokonał podziału parków, biorąc pod uwagę stopień intensywności użytkowania turystycznego i wyznaczył cztery jej klasy. Zabieg ten pozwolił na określenie typu przestrzeni turystycznej każdego z parków, co z kolei może być przydatne do badań nad funkcją turystyczną parków narodowych. Partyka z kolei scharakteryzował parki narodowe, przedstawił wielkość infrastruktury turystycznej dla każdego z nich i dokonał analizy ruchu turystycznego. Szerokie analizy zbiorcze parków wykonał także Smoleński (2006), dzieląc je pod względem wielkości, położenia oraz dostępności komunikacyjnej. W wielu opracowaniach naukowych związanych $\mathrm{z}$ ruchem turystycznym w parkach narodowych badacze poruszają zagadnienia związane z ekologią oraz problematykę udostępniania turystycznego obszaru parków i określają konsekwencje takiego działania (Partyka, 2002, 2010b). Gałązka (2009) zaprezentowała wyniki badań związanych z opinią turystów na temat turystyki zrównoważonej, a Mazurczak (2009) opisał realizację założeń turystyki ekologicznej i zrównoważonej w Parku Narodowym Ujście Warty. Badacze poświęcają wiele miejsca na omawianie negatywnych skutków występowania ruchu turystycznego w parkach narodowych (zob. np. Fidelus, 2008; Głuchowski, Nawrocka-Grześkowiak, 2013; Stasiak, 1997). Ruch turystyczny w parkach narodowych pod kątem rozwoju funkcji turystycznej analizowali m.in. Włodarczyk (1993) oraz Krakowiak (2000). Największą grupę opracowań stanowią analizy ruchu turystycznego, wykonywane dla konkretnych parków narodowych. Należy tu wymienić np. prace Dzioban (2013), Hibner (2013), Prędkiego (2015), Rogowskiego (2018), Semczuka (2012), Wieniawskiej-Raj (2007) i in. Analizy są prowadzone na wiele sposobów i dotyczą różnych aspektów ruchu turystycznego. Badacze omawiają jego wielkość, sezonowość, prezentują miejsca największej koncentracji, poruszają problemy związane $\mathrm{z}$ występowaniem turystyki $\mathrm{w}$ danym parku. Wiele opracowań powstało na podstawie przeprowadzanych przez autorów badań terenowych i pomiarów ruchu turystycznego. Zawierają one szczegółowe informacje na temat osób, które odwiedzają park, m.in. dotyczące ich płci, wykształcenia, pochodzenia, motywów przyjazdu oraz preferowanych form uprawianej turystyki. Dzięki tym danym naukowcy są w stanie ustalić profil turysty przybywającego do danego parku.
Zdaniem autora, mimo ogromnej różnorodności opracowań badawczych, brakuje publikacji, w których byłby poruszony problem dysproporcji wielkości ruchu turystycznego w parkach narodowych. Różnica pomiędzy liczbą turystów w parku najczęściej i najrzadziej odwiedzanym jest ogromna i sięga milionów osób. W artykule podjęto próbę wskazania głównych przyczyn zróżnicowania liczby turystów przybywających do parków. W tym celu, wykorzystując metodę desk research, dokonano analizy dostępnej literatury, w której został opisany ruch turystyczny w konkretnych parkach narodowych. Zwrócono uwagę na cechy parku, które w znacznym stopniu mogą wpływać na liczbę odwiedzających go turystów i na jej wahania. Inną zastosowaną metodą była analiza danych statystycznych publikowanych przez GUS. Najistotniejsze informacje zestawiono w tabelach i na wykresach. Wykonano także analizę dostępności turystycznej z wykorzystaniem serwisów Geoportal (2019) oraz Google Maps (2019). Efektem jest zbiorcza charakterystyka ruchu turystycznego polskich parków narodowych, ze szczególnym uwzględnieniem czynników, które mogą wpływać na zróżnicowanie liczby turystów.

\section{MONITORING RUCHU TURYSTYCZNEGO}

Z każdym kolejnym rokiem liczba osób, które odwiedzają parki narodowe, rośnie. $W$ niektórych parkach zjawisko to przebiega bardziej dynamicznie, w innych wolniej. Biorąc pod uwagę fakt, że są to obszary o unikatowych właściwościach środowiska, należy stwierdzić, że najważniejszą funkcją parków jako instytucji powinna być ochrona zasobów przyrodniczych. Tymczasem Ustawa z dnia 16 kwietnia 2004 r. o ochronie przyrody zobowiązuje parki do udostępniania tych obszarów w różnych celach. Wymagane jest odpowiednie zarządzanie ruchem turystycznym, tak by stopień jego oddziaływania na środowisko był jak najmniejszy. Parki narodowe potrzebują zatem bardzo dokładnych danych dotyczących ruchu turystycznego, a przede wszystkim informacji typu: kto i gdzie był, skąd przybył, kiedy i co robił, którędy wszedł, ile czasu spędził w parku itp. Wiedza na ten temat pozwoli na optymalne i racjonalne zarządzanie ruchem turystycznym, tak by nie wyrządzał on szkód środowisku. Jest to niezwykle istotne, ale bardzo trudne do realizacji. Sposobem na pozyskanie informacji na temat ruchu turystycznego w parku narodowym jest jego monitoring. Nie wszystkie parki dokonują jednak tego typu pomiarów, a w niektórych jest to wręcz niemożliwe. W każdym parku prowadzone są ewidencja i ciągła obserwacja zasobów środowiska na tym obszarze. Do prawidłowego funkcjonowania parku potrzeba też danych o ruchu turystycznym, dlatego 
śledzenie i analiza tego zjawiska są niezwykle istotne (Graja-Zwolińska, Spychała, 2014; Kruczek, Przybyło-Kisielewska, 2019). Kajala (2007) wymienia następujące metody pomiaru ruchu turystycznego:

- pośrednie, tj. liczenie turystów na podstawienp. ksiąg wejść i wyjść, sprzedaży biletów, wydawanych pozwoleń lub innych sposobów rejestracji;

- bezpośrednie, tj. liczenie turystów, np. na szlaku, obserwacje z powietrza;

- automatyczne, tj. wykorzystanie urządzeń pomiarowych.

Pomimo istnienia różnych metod pomiarowych wiele parków narodowych ma problem z pozyskiwaniem wiarygodnych i dokładnych danych o ruchu turystycznym. Najpopularniejszą metodą wykorzystywaną przez pracowników parków jest szacowanie wielkości i natężenia ruchu turystycznego na podstawie liczby sprzedanych biletów wstępu do parku, atrakcji na jego terenie lub na ścieżki edukacyjne (Spychała, Graja-Zwolińska, 2014), jednak w niektórych parkach narodowych nie sprawdza się to. Jak pisze Lawin (2000), liczenie turystów w ten sposób jest niemożliwe w Magurskim Parku Narodowym, gdyż nie odbywa się tam sprzedaż żadnych biletów. Z kolei Dzioban (2013) wskazuje na trudności w monitoringu ruchu turystycznego tą metodą w Kampinoskim Parku Narodowym, który ma praktycznie otwarte granice i można do niego wejść z każdej strony. Ponadto liczba wykupionych biletów nie daje całościowego obrazu ruchu turystycznego, ponieważ $\mathrm{w}$ danym parku mogą być one sprzedawane wyłącznie na jakąś atrakcję lub tylko w kilku punktach, podczas gdy turyści odwiedzają wiele miejsc. Jastrzębski (2009) przedstawił wady wykorzystania tej metody w Świętokrzyskim Parku Narodowym. Wprawdzie jest tam prowadzona ewidencja sprzedanych biletów wstępu do konkretnych miejsc, np. na Święty Krzyż, jednak granice parku da się przekroczyć w kilku innych punktach, a osoby które tamtędy wchodzą na jego teren, nie są $\mathrm{w}$ żaden sposób zliczane.

Inną metodą monitoringu ruchu turystycznego jest liczenie turystów z wykorzystaniem ankiety, w której zadawane są pytania o motywy i preferencje dotyczące wyboru miejsca wyjazdu. Pozwala to nie tylko na pozyskanie danych liczbowych, ale także na stworzenie profilu turysty, który odwiedza dany park. Tego typu badania realizowane są $\mathrm{w}$ wielu parkach narodowych, m.in. Babiogórskim, Gorczańskim, Tatrzańskim, Karkonoskim, Gór Stołowych, a w ciągu ostatnich lat kolejne systematycznie wdrażają ten sposób pomiaru. Działania te często realizowane są nie tylko przez pracowników, ale także przez osoby prowadzące badania terenowe oraz przez wolontariuszy. Opisywana metoda jest czasochłonna i kosztowna. Przygotowanie odpowiedniego arkusza zajmuje dużo czasu, podobnie jak zebranie danych i ich późniejsza analiza. Pomiary trzeba wykonywać regularnie, co wiąże się z zaangażowaniem w te działania wielu osób. Poza liczeniem turystów monitoruje się także samochody. Sprawdza się ich liczbę oraz spisuje numery rejestracyjne $w$ celu poznania regionów, z których przyjeżdżają turyści.

Najefektywniejszą metodą wydaje się wykorzystanie elektronicznych urządzeń pomiarowych. Jest ona stosowana w 14 parkach. Używa się w nich systemu Eco-Counter firmy Amreco, złożonego z czujników pyroelektrycznych, czujników ruchu i innych urządzeń, które wykrywając drgania oraz działając $w$ podczerwieni, zliczają przechodzących turystów. Metoda ta ma wiele zalet: nie wymaga angażowania dodatkowych osób do dokonywania pomiarów, jest szybka i łatwa w obsłudze, jednak posiada również wady. Urządzenia te, ze względu na poziom zaawansowania technologii użytej do ich wykonania, są bardzo drogie. Czujniki niekiedy ulegają zniszczeniu lub są kradzione. Nierzadko przytrafiają się też błędy w pomiarach. Buchwał i Fidelus (2010) oraz Hibner (2014) zwrócili uwagę na błędy pomiarowe tych urządzeń podczas monitorowania ruchu turystycznego w Tatrzańskim Parku Narodowym. Zdarza się, że urządzenie nie rozpoznaje dwóch idących obok siebie turystów i liczy ich jako jedną osobę, podczas dużego obciążenia szlaku pomija niektórych ludzi, nogi wysokich odwiedzających uznaje za dwie osoby, w ogóle nie rejestruje osób niskich lub w pomiarach uwzględnia zwierzęta. Problem pojawia się również wtedy, gdy czujnik jest nieodpowiednio ustawiony. Pomimo licznych nieprawidłowości w działaniu tego typu urządzeń, w ciągu ostatnich lat omawiana metoda zaczyna być stosowana w kolejnych parkach. Jak wskazuje Rogowski (2018), taki system pozwala pozyskiwać wiarygodne dane dla Parku Narodowego Gór Stołowych, a w szczególności jest źródłem informacji na temat obciążenia szlaków czy popularności atrakcji i różnych obszarów parku. Opracowano także sposoby niwelowania błędów występujących w pomiarach czujników, np. w Tatrzańskim Parku Narodowym przez pewien czas pracownik lub wolontariusz przebywa w pobliżu czujnika i sam liczy turystów. Następnie wyniki są porównywane z danymi z czujnika. W miarę wielkości błędu korygowane są ustawienia urządzenia i test wykonuje się ponownie, aż do momentu uzyskania zbliżonych wyników. Mimo wad metoda ta wydaje się najskuteczniejsza. Czujniki można ustawić w wielu miejscach w parku i pozyskiwać dane z dużego obszaru.

Mimo że każda z metod ma wady, monitorowanie ruchu turystycznego na obszarze parków narodowych jest bardzo istotną kwestią. Pozwala na oszacowanie liczby turystów, określenie miejsc, gdzie jest ich najwięcej, i punktów, w których wchodzą do parku, oraz uzyskanie innych danych. Wszystkie te informacje wspomagają właściwe zarządzanie ruchem turystycznym. 


\section{RUCH TURYSTYCZNY W PARKACH NARODOWYCH}

W tej części artykułu zaprezentowane zostały wybrane dane ilościowe dotyczące parków narodowych, pochodzące z zestawień statystycznych GUS (Ochrona Środowiska 2008, 2008; Ochrona Środowiska 2018, 2018). Zostały także przygotowane własne analizy, które pozwolą na wskazanie przyczyn zróżnicowania liczby turystów odwiedzających parki.

\subsection{WIELKOŚĆ RUCHU TURYSTYCZNEGO W PARKACH NARODOWYCH W POLSCE}

Na rys. 1 zaprezentowano rozmieszczenie parków narodowych w Polsce, a na rys. 2 - wielkość ruchu turystycznego w 2007 i 2017 r. Można zauważyć, że w większości parków narodowych liczba turystów zwiększyła się w uwzględnionym w analizie dziesięcioleciu. W przypadku kilku parków (Wolińskiego, Karkonoskiego, Wielkopolskiego, Magurskiego, Kampinoskiego) liczba ta się nie zmieniła. Zdaniem autora podane wartości są nieprecyzyjne i wynikają z braku dokładnych danych o ruchu turystycznym w tych parkach, co sprawia, że należy je uznać za szacunkowe i obarczone błędem. Wymienione parki mają problemy

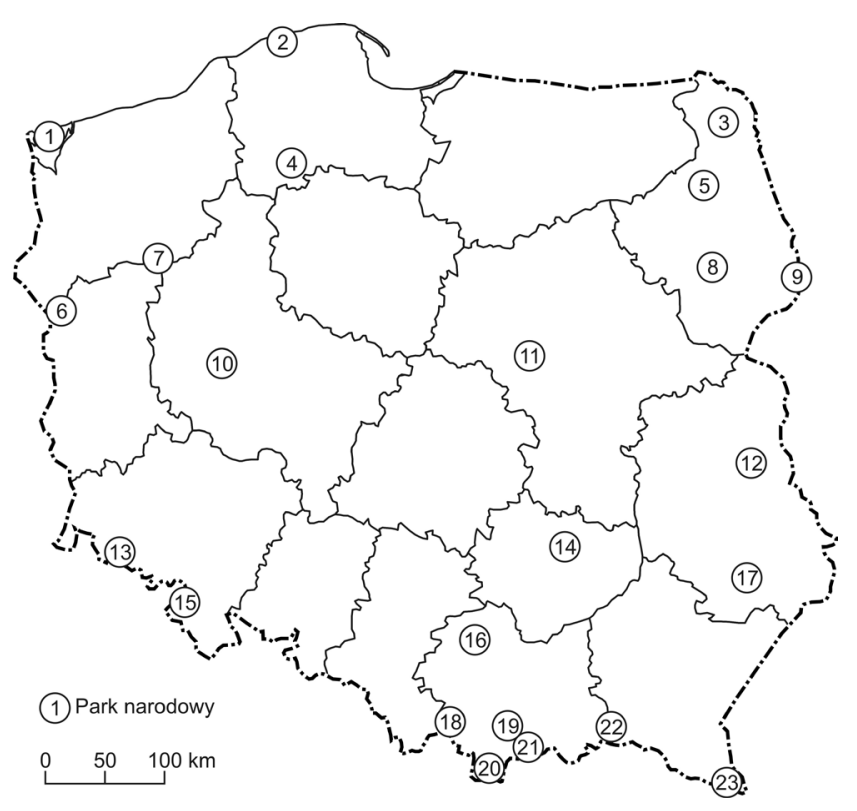

Rysunek 1. Parki narodowe w Polsce. 1 - Woliński, 2 - Słowiński, 3 - Wigierski, 4 - Bory Tucholskie,

5 - Biebrzański, 6 - Ujście Warty, 7 - Drawieński, 8 - Narwiański, 9 - Białowieski, 10 - Wielkopolski, 11 - Kampinoski, 12 - Poleski, 13 - Karkonoski, 14 - Świętokrzyski, 15 - Gór Stołowych, 16 - Ojcowski, 17 - Roztoczański, 18 - Babiogórski, 19 - Gorczański, 20 - Tatrzański, 21 - Pieniński, 22 - Magurski, 23 - Bieszczadzki Źródło: opracowanie autora

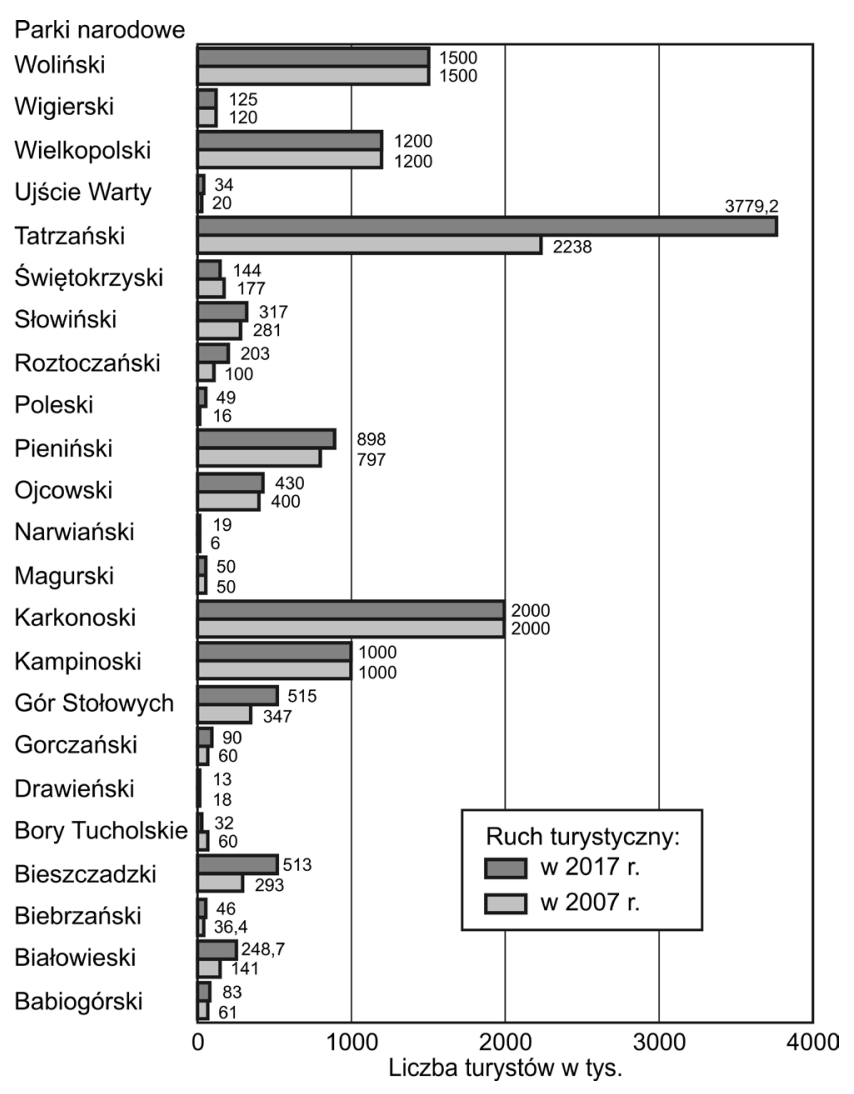

Rysunek 2. Wielkość ruchu turystycznego w 2007 i 2017 r. Źródło: opracowanie autora na podstawie danych GUS

z monitoringiem ruchu turystycznego, ponieważ można do nich wejść w wielu miejscach, nie prowadzi się sprzedaży biletów lub pomiar ruchu turystycznego jest z jakichś przyczyn niemożliwy. Patrząc na ogólne tendencje wzrostowe, należy stwierdzić, że parki te może odwiedzać obecnie zdecydowanie więcej turystów niż kiedyś. Są też parki, w których odnotowano spadek liczby turystów. Należą do nich parki narodowe: Bory Tucholskie, Drawieński i Świętokrzyski.

Analizując rozkład przestrzenny parków narodowych oraz wielkość ruchu turystycznego, można zauważyć, że parki o największej liczbie turystów leżą $\mathrm{w}$ regionach, które są najchętniej wybierane jako cel podróży turystycznych, tj. morze, jeziora, góry. Parki rzadziej uczęszczane znajdują się na obszarach leśnych, wodno-błotnych, podmokłych. W grupie najrzadziej odwiedzanych są też parki znajdujące się w górach, a przecież teoretycznie te obszary odwiedza największa liczba osób. Informacje te wskazują na występowanie czynników różnicujących ruch turystyczny w górskich parkach narodowych, a położenie geograficzne jest tylko jednym z wielu takich uwarunkowań.

W celu odnalezienia innych przyczyn zróżnicowania liczby osób odwiedzających parki narodowe zestawiono liczbę turystów z długością istnienia parku (rys. 3). Na przedstawionej piramidzie widać, że jest grupa parków, w przypadku których okres funkcjonowania może mieć wpływ na liczbę turystów. Najchętniej od- 


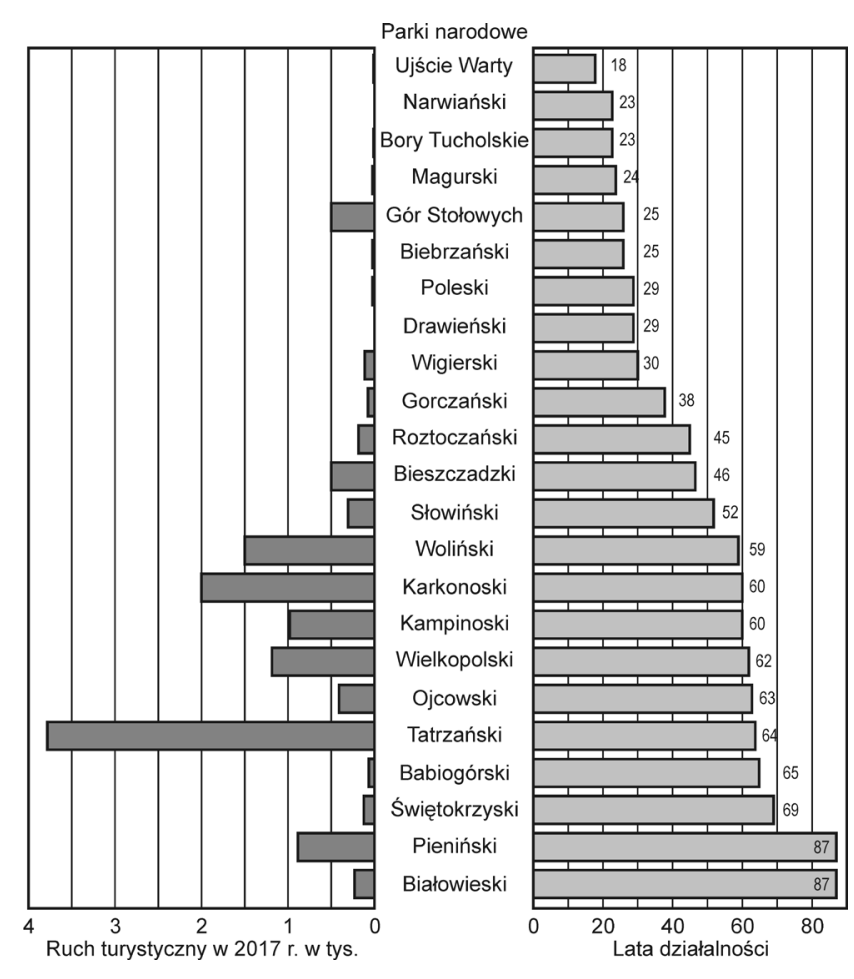

Rysunek 3. Piramida liczby turystów i czasu funkcjonowania parku narodowego Źródło: opracowanie autora

wiedzane parki prowadzą swoją działalność od ponad 60 lat. Być może przez tak długi okres funkcjonowania dany park narodowy opracował skuteczną metodę zarządzania ruchem turystycznym, zdobył uznanie w oczach turystów i został odpowiednio przygotowany do uprawiania turystyki na swoim obszarze. Objęcie danej przestrzeni formą ochrony, jaką jest park narodowy, powoduje, że staje się ona bardziej wartościowa i atrakcyjna w odczuciu turystów. Dlatego też można założyć, że im dłużej dany park funkcjonuje, tym bardziej jego walory są postrzegane jako unikatowe. $Z$ danych zaprezentowanych $w$ górnej części piramidy (rys. 3) wynika, że im krócej dany park istnieje, tym mniej osób go odwiedza. Prawdopodobnie przyczyną takiego stanu rzeczy jest to, że turyści dotychczas nie poznali w należytym stopniu zasobów parku lub obszar ten nie został odpowiednio przygotowany do obsługi ruchu turystycznego, co można również wytłumaczyć faktem, że nadrzędnym celem parków narodowych jest ochrona środowiska. Ponad to wizerunek parku mógł nie zostać jeszcze odpowiednio wypromowany, w związku z czym miejsce to nie jest postrzegane przez turystów w taki sposób, jak parki cieszące się największą popularnością. Długi okres działalności pozwolił najpopularniejszym parkom na wypracowanie odpowiedniej strategii zarządzania ruchem turystycznym, przygotowania odpowiedniej oferty oraz akcji edukacyjnych, przez co dany obszar miał szansę zyskać większe uznanie wśród turystów. Kilka parków narodowych odbiega jednak od przyjętego założenia. Do Parku Narodowego Gór Stołowych, który w porównaniu $\mathrm{z}$ innymi parkami powstał stosunkowo niedawno, przybywa kilkaset tysięcy turystów więcej niż np. do starszego od niego o ponad 60 lat Białowieskiego czy Świętokrzyskiego Parku Narodowego. Jak pisze Rogowski (2017), Park Narodowy Gór Stołowych odznacza się unikatowymi walorami, dzięki którym jest zaliczany do obszarów o podstawowym znaczeniu dla turystyki wypoczynkowej. Dodatkowo większa liczba turystów w tym miejscu niż w starszych parkach może wynikać z położenia Parku Narodowego Gór Stołowych, który znajduje się w pobliżu popularnych miejscowości turystyczno-uzdrowiskowych (Duszniki-Zdrój, Polanica-Zdrój) oraz większych miast (np. Kłodzka). Babiogórski i Białowieski Park Narodowy leżą zdecydowanie dalej od miejscowości węzłowych oraz posiadają mniejszą liczbę szlaków turystycznych. Natomiast do Świętokrzyskiego Parku Narodowego licznie przybywają wycieczki i grupy zorganizowane oraz pielgrzymi. Mimo dobrego skomunikowania i położenia blisko Kielc, można założyć, że walory parku mają zasięg regionalny i wzbudzają zainteresowanie jedynie konkretnych grup odwiedzających.

\subsection{DOSTĘPNOŚĆ KOMUNIKACYJNA}

Kolejnym etapem analiz było określenie poziomu dostępności komunikacyjnej wszystkich parków narodowych. Podobne badania przeprowadził Smoleński (2006), który biorąc pod uwagę dostępność parków, podzieliłje na: łatwo dostępne, takie, do których dojazd jest utrudniony, a także trudno dostępne. Sklasyfikował je również pod względem czasu trwania sezonu turystycznego.

Autor niniejszego artykułu, korzystając z narzędzi Geoportal oraz Google Maps, dokonał analizy dostępności komunikacyjnej w następujący sposób: oszacował odległość od miejscowości węzłowej oraz sprawdził dostępność dróg i środków transportu, jakimi można dostać się do poszczególnych parków (tab. 1). Za kryterium obrał odległość nie większą niż 25 kilometrów, z racji tego, że przy obecnym poziomie rozwoju sieci transportowej dystans ten można pokonać mniej więcej w pół godziny, w zależności od środka transportu. Autor przeprowadził także analizę odległości parku narodowego od aglomeracji miejskiej (rys. 4), a także aglomeracji od parku w promieniu $100 \mathrm{~km}$ (rys. 5). Ekwidystanty zostały wyznaczone co $25 \mathrm{~km}$, dzięki czemu możliwe było również oszacowanie czasu dojazdu do parku, przy założeniu, że odległość tę da się pokonać w pół godziny (100 km $\rightarrow$ ok. 2 godzin). Czas dojazdu do każdego parku będzie jednak inny, ze względu na zróżnicowany stopień infrastruktury komunikacyjnej (np. występowanie autostrad i dróg szybkiego ruchu w pobliżu parku znacznie skróci podróż). Przyjęto, że za aglomeracje znajdujące się w pobli- 
Tabela 1. Dostępność komunikacyjna parków narodowych

\begin{tabular}{|c|c|c|c|c|c|c|c|c|c|}
\hline \multirow[b]{2}{*}{$\begin{array}{c}\text { Park } \\
\text { Narodowy }\end{array}$} & \multicolumn{7}{|c|}{ Występowanie w odległości do $25 \mathrm{~km}$ od granic parku } & \multirow[b]{2}{*}{$\begin{array}{l}\text { Występowanie } \\
\text { aglomeracji } \\
\text { w odległości } \\
50 \mathrm{~km} \\
\text { od granic } \\
\text { parku }\end{array}$} & \multirow[b]{2}{*}{ Suma } \\
\hline & $\begin{array}{c}\text { węzeł } \\
\text { autostradowy }\end{array}$ & $\begin{array}{c}\text { droga } \\
\text { krajowa }\end{array}$ & $\begin{array}{c}\text { droga } \\
\text { woje- } \\
\text { wódzka }\end{array}$ & $\begin{array}{c}\text { stacja/ } \\
\text { przystanek } \\
\text { kolejowy }\end{array}$ & $\begin{array}{c}\text { drogowa } \\
\text { komunikacja } \\
\text { publiczna }\end{array}$ & $\begin{array}{l}\text { miejscowość } \\
\text { węzłowa } \\
\text { - miasto } \\
\text { do } 10 \text { tys. } \\
\text { mieszkańców }\end{array}$ & \begin{tabular}{|c|} 
miejscowość \\
węzłowa \\
- miasto \\
powyżej \\
10 tys. \\
mieszkańców \\
\end{tabular} & & \\
\hline Babiogórski & & & $x$ & & $x$ & $x$ & & $\times$ & 4 \\
\hline Białowieski & & & $\times$ & $\times$ & $\times$ & $\times$ & $\times$ & & 5 \\
\hline Biebrzański & & $\times$ & $\times$ & $\times$ & $\times$ & $\times$ & $\times$ & $\times$ & 7 \\
\hline Bieszczadzki & & & $\times$ & & $\times$ & $x$ & & & 3 \\
\hline $\begin{array}{l}\text { Bory } \\
\text { Tucholskie }\end{array}$ & & $x$ & $\times$ & $\times$ & $x$ & $\times$ & $\times$ & & 6 \\
\hline Drawieński & & $x$ & & $x$ & $x$ & $x$ & & & 4 \\
\hline Gorczański & & & $x$ & $x$ & $x$ & $x$ & $x$ & $x$ & 6 \\
\hline $\begin{array}{l}\text { Gór } \\
\text { Stołowych }\end{array}$ & & $x$ & $x$ & $x$ & $x$ & $x$ & $x$ & $x$ & 7 \\
\hline Kampinoski & $x$ & $x$ & $x$ & $x$ & $x$ & $x$ & $x$ & $\times$ & 8 \\
\hline Karkonoski & & $x$ & $\times$ & $x$ & $x$ & $x$ & $\times$ & $x$ & 7 \\
\hline Magurski & & $x$ & $\times$ & & $\times$ & $\times$ & & $\times$ & 5 \\
\hline Narwiański & $x$ & $x$ & $\times$ & $x$ & $\times$ & $\times$ & $\times$ & $x$ & 8 \\
\hline Ojcowski & & $x$ & $x$ & & $x$ & $x$ & $x$ & $x$ & 6 \\
\hline Pieniński & & & $x$ & & $x$ & $x$ & $x$ & $x$ & 5 \\
\hline Poleski & & $x$ & $x$ & & $x$ & $x$ & & & 4 \\
\hline Roztoczański & & $x$ & $\times$ & $x$ & $x$ & $x$ & & & 5 \\
\hline Słowiński & & $x$ & $\times$ & $x$ & $x$ & $x$ & & & 5 \\
\hline Świętokrzyski & & $x$ & $\times$ & & $x$ & $\times$ & $x$ & $\times$ & 6 \\
\hline Tatrzański & & $\times$ & $\times$ & $x$ & $\times$ & $\times$ & $x$ & & 6 \\
\hline Ujście Warty & & $x$ & $x$ & $x$ & $x$ & $x$ & $x$ & & 6 \\
\hline Wielkopolski & $\times$ & $\times$ & $\times$ & $\times$ & $\times$ & $\times$ & $x$ & $\times$ & 8 \\
\hline Wigierski & $x$ & $\times$ & $\times$ & $\times$ & $x$ & $\times$ & $\times$ & & 7 \\
\hline Woliński & & $\times$ & $\times$ & $\times$ & $\times$ & $\times$ & $\times$ & & 6 \\
\hline Suma & 4 & 18 & 22 & 16 & 23 & 23 & 16 & 12 & \\
\hline
\end{tabular}

Źródło: opracowanie autora.

żu parku uznaje się te oddalone o maksymalnie $50 \mathrm{~km}$. Pokonanie tej odległości powinno zająć nie więcej niż godzinę, co w przypadku wielu parków może mieć zasadniczy wpływ na częstotliwość odwiedzin oraz charakter ruchu turystycznego. W analizie uwzględniono 27 aglomeracji miejskich Polski, które wyszczególnili Klimska i Swianiewicz (2005). Najbliżej aglomeracji położone są parki: Kampinoski, Wielkopolski, Świętokrzyski, Ojcowski. W odległości nie większej niż 50 km od dużego miasta położonych jest 8 parków. W promieniu 75 km od każdego parku znajduje się aglomeracja. Warto zaznaczyć, że im bliżej miasta jest usytuowany park, tym więcej turystów go odwiedza. Dzięki położeniu parku narodowego w pobliżu aglomeracji miejskiej dostanie się do niego różnymi środkami komunikacji jest znacznie łatwiejsze. Dodatkowo metropolia może stanowić zaplecze turystyczne parku.
Jak wynika z rys. 5, żadne duże miasto nie leży bliżej niż 75 km od czterech parków (Bory Tucholskie, Drawieński, Poleski, Ujście Warty), w których odnotowuje się najmniej turystów. Peryferyjnie położone są również parki: Bieszczadzki, Słowiński i Wigierski, jednak w tym przypadku sytuacja jest nieco inna. Po pierwsze te trzy obszary odwiedza znacznie więcej osób niż parki wspomniane wcześniej. Kolejnym czynnikiem może być fakt, że są to parki bogate w walory, które zdaniem turystów wpływają na atrakcyjność tych obszarów. Słowiński i Wigierski Park Narodowy położone są w bezpośrednim sąsiedztwie większych miast o silnie rozwiniętej funkcji turystycznej (Łeba, Suwałki), które nie zostały jednak sklasyfikowane jako aglomeracje. Natomiast Bieszczadzki Park Narodowy, mimo że nie znajduje się blisko dużych miast i trudniej do niego dojechać niż do innych parków, otoczony jest przez 


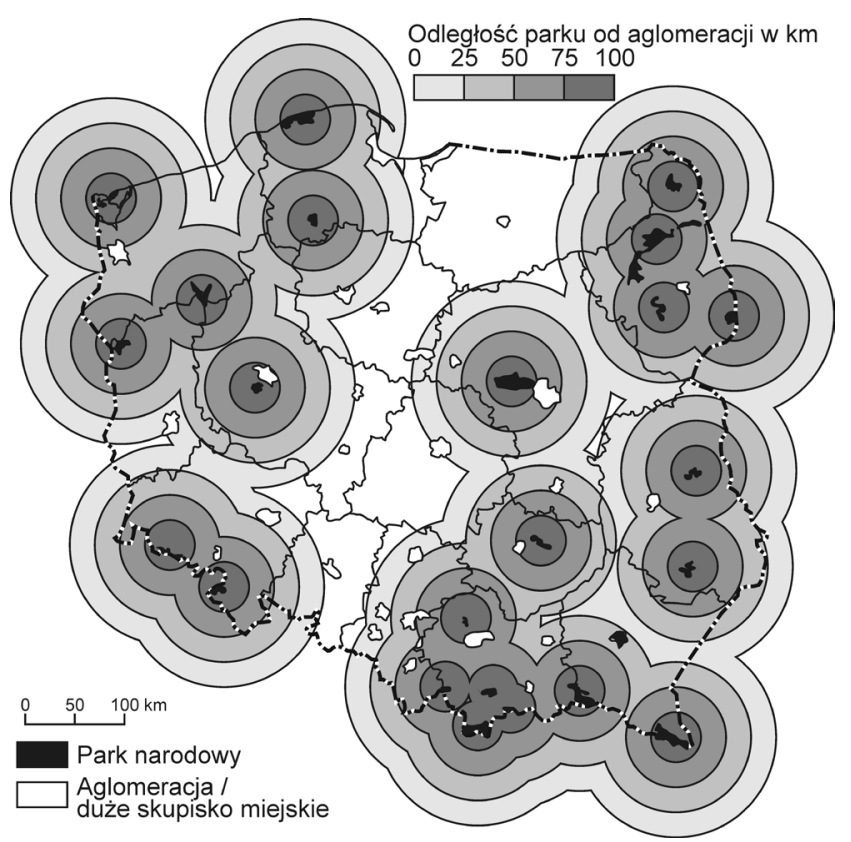

Rysunek 4. Odległość parków narodowych od aglomeracji miejskich

Źródło: opracowanie autora

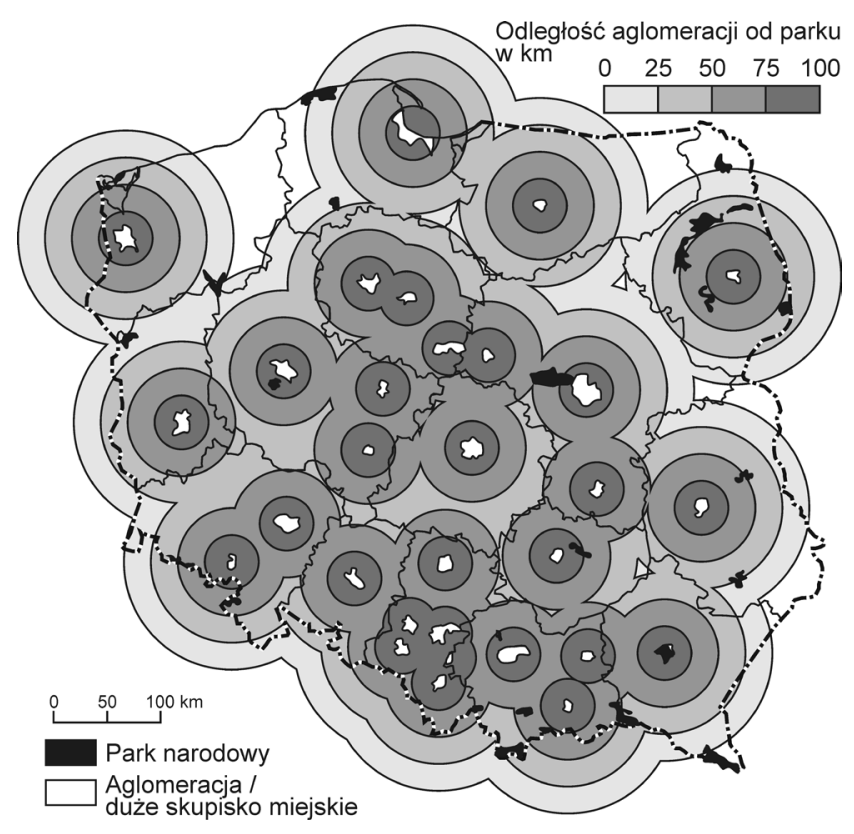

Rysunek 5. Odległość aglomeracji od parków narodowych Źródło: opracowanie autora

kilka miejscowości o dobrze rozwiniętej funkcji turystycznej, a jego walory krajobrazowe znajdują uznanie w oczach turystów. Dodatkowo dostanie się do niego jest znacznie ułatwione dzięki węzłowi autostrady A4

Jedynie w przypadku ośmiu aglomeracji miejskich park narodowy znajduje się w zasięgu $50 \mathrm{~km}$. Trzy miasta, tj. Olsztyn, Opole i Toruń, nie leżą w promieniu $100 \mathrm{~km}$ od żadnego parku. Można również stwierdzić, że dwa miasta - Nowy Sącz i Białystok - są otoczone przez parki narodowe, gdyż w odległości do $50 \mathrm{~km}$ od nich zlokalizowane są po trzy parki. Można uznać, że w pobliżu Nowego Sącza znajduje się również Tatrzański Park Narodowy, ponieważ pomimo że odległość między tym parkiem a miastem jest większa niż $50 \mathrm{~km}$, to pokonanie jej zajmuje maksymalnie 2 godziny. Widać więc, że dystans między parkiem a aglomeracją oraz czas dojazdu często mają zasadnicze znaczenie, $\mathrm{np}$. w przypadku parków położonych bezpośrednio przy dużym skupisku miejskim, którego mieszkańcy stanowią większość odwiedzających te miejsca osób. Niekiedy położenie blisko aglomeracji lub jej brak nie ma tak dużego znaczenia, np. w odniesieniu do parków na obszarach wodno-błotnych lub w dolinach rzek. Zdaniem autora w wielu przypadkach większe znaczenie od położenia $w$ pobliżu aglomeracji miejskiej ma występowanie w sąsiedztwie parku ośrodków o silnie rozwiniętej funkcji turystycznej i ugruntowanej renomie, stanowiących zaplecze turystyczne parku. Bardzo często są to małe miasta, a nawet wsie.

$\mathrm{Z}$ zaprezentowanych materiałów wynika, że dostępność komunikacyjna parków narodowych w znaczący sposób wpływa na liczbę turystów, którzy je odwiedzają. Może się wydawać, że wszystkie parki narodowe są dobrze skomunikowane i położone w pobliżu miejscowości węzłowej. Jednak występują znaczne różnice. Parki narodowe, które cieszą się dużą popularnością wśród turystów, zazwyczaj są położone w pobliżu miasta lub aglomeracji. Nierzadko, jak w przypadku Karkonoskiego, Tatrzańskiego czy Wolińskiego Parku Narodowego, są to miejscowości o dobrze rozwiniętej funkcji turystycznej. Dla niektórych parków istotne znaczenie ma fakt, że znajdują się one w pobliżu dużej aglomeracji miejskiej, która jest nie tylko zapleczem turystycznym, ale również ma duży wpływ na rozkład ruchu turystycznego. Kampinoski czy Wielkopolski Park Narodowy to typowe parki podmiejskie, które służą mieszkańcom pobliskich miast jako obszary rekreacyjno-wypoczynkowe. Dzięki łatwemu dostępowi do dużych miejscowości dotarcie do parku jest znacznie ułatwione. Drawieński Park Narodowy położony jest najdalej od jakiegokolwiek miasta. Prowadzi do niego droga krajowa, ale dojazd innymi środkami transportu stanowi problem. Gdy w pobliżu parku nie ma miejscowości węzłowej, pobyt w nim jest bardzo utrudniony. Turysta zmuszony jest pokonać dużą odległość oraz poświęcić zdecydowanie więcej czasu, aby dostać się w to miejsce. Podobnie jest w przypadku Babiogórskiego i Gorczańskiego Parku Narodowego, które również są oddalone od miejscowości węzłowych, w związku z czym dotarcie tam zabiera dużo czasu. Być może jest to czynnik, który sprawia, że mimo iż są one zlokalizowane w górach, odwiedza je znacznie mniej turystów niż inne parki o podobnym charakterze. Warto jednak zauważyć, że dojazd do tych parków ułatwia droga krajowa nr 47, czyli popularna zakopianka, która 
w ostatnich latach odcinkowo przekształcana jest w trasę szybkiego ruchu w celu usprawnienia i ułatwienia podróżowania.

\subsection{INFRASTRUKTURA TURYSTYCZNA}

Zgodnie z Ustawa z dnia 16 kwietnia 2004 r. o ochronie przyrody (2004) turystyka w parkach narodowych może odbywać się na wytyczonych szlakach, dzięki którym ruch turystyczny w parku narodowym rozmieszczony jest $\mathrm{w}$ sposób liniowy. Jednak same wytyczone trasy nie wystarczą. Do prawidłowej obsługi turystów na szlaku instalowane lub budowane są specjalne urządzenia oraz elementy infrastruktury turystycznej, np. schroniska, schrony, wiaty, wyciagi itp. Na rys. 6 zaprezentowano długość szlaków turystycznych w kilometrach dla każdego parku, a w tab. 2 wskazano liczbę wybranych elementów infrastruktury turystycznej. Długość szlaków turystycznych w parku zależy w przeważającym stopniu od jego kształtu, ukształtowania powierzchni oraz rodzaju chronionych zasobów środowiska. Dlatego też dużą liczbą szlaków cieszą się parki górskie o atrakcyjnych walorach krajobrazowych, zlokalizowanych w różnych częściach parku. Szlaki wytycza się, aby umożliwić odkrywanie tych walorów turystom z zachowaniem możliwie jak najmniejszej ingerencji w środowisko. Szlaki na obszarach górskich przebiegają w sposób nieregularny, tworząc skomplikowane sieci i jednocześnie omijając miejsca najcenniejsze pod względem przyrodniczym. Wiele szlaków turystycznych jest wytyczonych w parkach nizinnych, położonych w pobliżu dużych miast. Służą mieszkańcom jako łatwo dostępne tereny rekreacyjne, przeznaczone na krótkotrwałe wizyty. Stosunkowo dużo szlaków przebiega przez parki położone na obszarach pojeziernych, wodno-błotnych oraz w dolinach rzek. Znaczna część szlaków pokrywa się ze ścieżkami leśnymi, a przy zliczaniu długości uwzględniane są również szlaki wodne (Stasiak, Śledzińska, Włodarczyk, 2014).

Biorąc pod uwagę długość szlaków, niektóre parki o najwyższej frekwencji turystycznej mają również najdłuższą liczbę szlaków. Jednak zdarzają się także parki o małej liczbie szlaków, ale licznie odwiedzane przez turystów, i odwrotnie: są parki, w których

Tabela 2. Liczba wybranych elementów infrastruktury turystycznej

\begin{tabular}{|c|c|c|c|c|c|c|c|c|}
\hline Park Narodowy & Schroniska & $\begin{array}{c}\text { Domy } \\
\text { wczasowe }\end{array}$ & $\begin{array}{c}\text { Kempingi, } \\
\text { biwaki }\end{array}$ & Schrony & $\begin{array}{l}\text { Nartostrady } \\
\quad(w \mathrm{~km})\end{array}$ & $\begin{array}{l}\text { Kolejki } \\
\text { linowe }\end{array}$ & Wyciagi & $\begin{array}{c}\text { Trasy } \\
\text { wyczynowe }\end{array}$ \\
\hline Babiogórski & 1 & 0 & 1 & 14 & 6,0 & 0 & 0 & 0 \\
\hline Białowieski & 0 & 1 & 0 & 0 & 0,0 & 0 & 0 & 0 \\
\hline Biebrzański & 0 & 0 & 3 & 31 & 0,0 & 0 & 0 & 0 \\
\hline Bieszczadzki & 3 & 0 & 3 & 19 & 0,0 & 0 & 0 & 0 \\
\hline Bory Tucholskie & 0 & 0 & 0 & 0 & 0,0 & 0 & 0 & 0 \\
\hline Drawieński & 0 & 0 & 6 & 1 & 0,0 & 0 & 0 & 0 \\
\hline Gorczański & 0 & 0 & 2 & 3 & 0,3 & 0 & 0 & 0 \\
\hline Gór Stołowych & 2 & 3 & 0 & 13 & 34,0 & 0 & 0 & 0 \\
\hline Kampinoski & 1 & 0 & 0 & 87 & 0,0 & 0 & 0 & 0 \\
\hline Karkonoski & 10 & 0 & 0 & 3 & 14,7 & 4 & 9 & 0 \\
\hline Magurski & 0 & 0 & 0 & 13 & 0,0 & 0 & 0 & 0 \\
\hline Narwiański & 0 & 0 & 2 & 0 & 0,0 & 0 & 0 & 0 \\
\hline Ojcowski & 0 & 0 & 1 & 1 & 0,0 & 0 & 0 & 0 \\
\hline Pieniński & 0 & 0 & 0 & 3 & 0,0 & 0 & 0 & 0 \\
\hline Poleski & 0 & 0 & 4 & 27 & 0,0 & 0 & 0 & 0 \\
\hline Roztoczański & 0 & 0 & 0 & 7 & 0,0 & 0 & 0 & 0 \\
\hline Słowiński & 0 & 0 & 0 & 37 & 0,0 & 0 & 0 & 0 \\
\hline Świętokrzyski & 2 & 0 & 1 & 4 & 0,0 & 0 & 0 & 0 \\
\hline Tatrzański & 8 & 0 & 2 & 0 & 24,8 & 7 & 3 & 3 \\
\hline Ujście Warty & 0 & 0 & 0 & 0 & 0,0 & 0 & 0 & 0 \\
\hline Wielkopolski & 0 & 0 & 1 & 20 & 0,0 & 0 & 0 & 0 \\
\hline Wigierski & 0 & 5 & 4 & 92 & 15,3 & 0 & 0 & 0 \\
\hline Woliński & 0 & 0 & 0 & 10 & 0,0 & 0 & 0 & 0 \\
\hline
\end{tabular}

Źródło: opracowanie autora na podstawie danych GUS. 


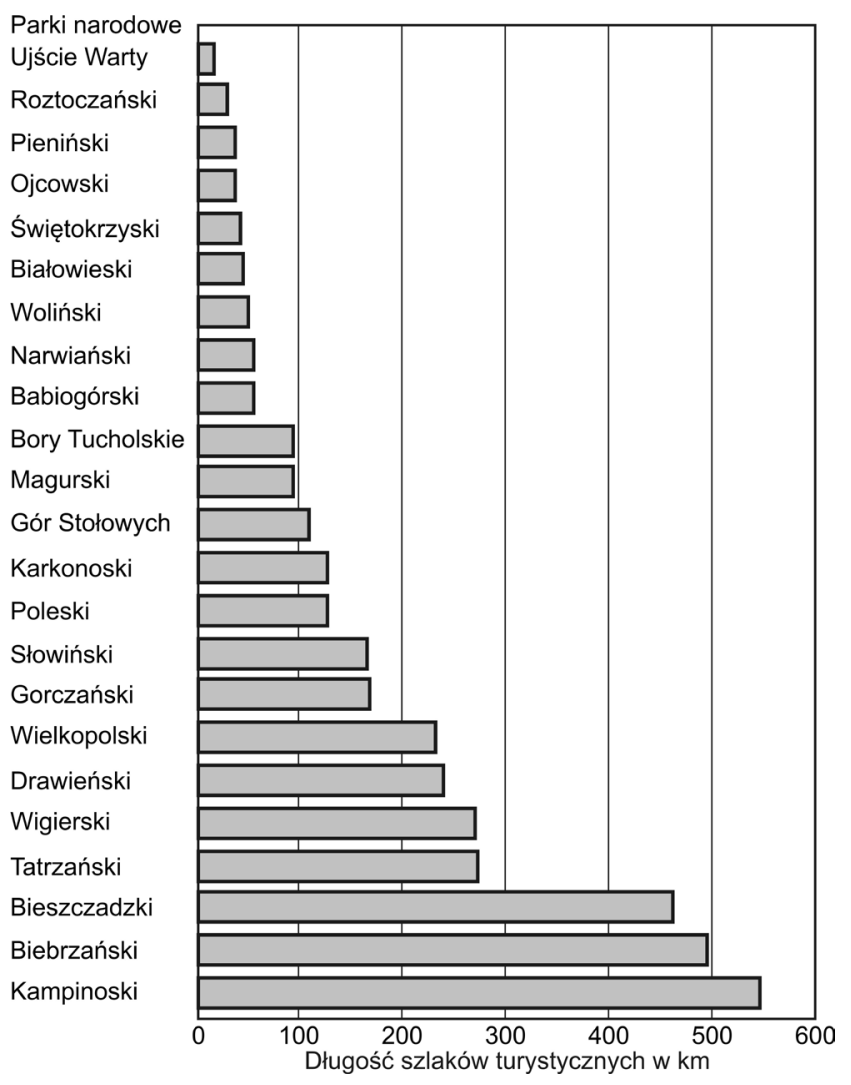

Rysunek 6. Długość szlaków w parkach narodowych Źródło: opracowanie autora na podstawie danych GUS

szlaków turystycznych jest dużo, a mimo to frekwencja turystyczna jest niska, np. Biebrzański Park Narodowy. Wyjaśnienie tego paradoksu może przynieść analiza innej infrastruktury turystycznej. Jak widać, na terenie Biebrzańskiego Parku Narodowego istnieją schrony przeciwdeszczowe i miejsca kempingowe. Większość parków o mniejszej długości szlaków turystycznych nie posiada jednak zbyt wielu innych elementów infrastruktury turystycznej. Warto zauważyć, że pod tym względem wyróżniają się górskie parki narodowe. Można stwierdzić, że przyczyną takiego stanu rzeczy jest położenie geograficzne. Obszary górskie umożliwiają uprawianie różnych dyscyplin sportu (np. jazda na nartach czy wspinaczka) i form turystyki, więc niezbędna jest odpowiednia infrastruktura $w$ celu zapewnienia właściwego poziomu obsługi. Podobnie jest w przypadku Wigierskiego Parku Narodowego, który również ma zróżnicowaną infrastrukturę turystyczną związaną z uprawianiem różnych form turystyki wodnej.

\subsection{SEZONOWOŚĆ RUCHU TURYSTYCZNEGO}

Kolejnym krokiem była analiza sezonowości ruchu turystycznego, do której wybrano cztery parki narodowe, reprezentujące różne regiony geograficzne. Taki zabieg pozwolił na poznanie cech ruchu turystycznego, charakterystycznych dla danej grupy parków. Na rys. 7 zaprezentowano wskaźniki sezonowości, obliczone dla czterech parków narodowych: Tatrzańskiego, Wigierskiego, Biebrzańskiego oraz Bory Tucholskie. Czerwoną linią zaznaczono wartości powyżej 100\% (wartość średnia z 12 miesięcy), które ukazują przebieg granic sezonów turystycznych. Wspólną cechą wszystkich parków objętych badaniem jest to, że w miesiącach wakacyjnych wykazują bardzo wysokie wartości wskaźnika. Jest to zjawisko typowe dla obszaru Polski. O sezonowości ruchu turystycznego decydują przede wszystkim warunki klimatyczne oraz stan pogody w ciagu roku. Najkorzystniejsze warunki do uprawiania turystyki występują właśnie w miesiącach wakacyjnych: wysoka temperatura, wielkość usłonecznienia, długość dnia. Wtedy też wiele osób ma czas wolny od pracy i wyjeżdża na urlopy letnie (Błażejczyk, Kunert, 2011; Koźmiński, Michalska, 2016). Wskaźniki informują jednak także o cechach charakterystycznych dla każdego parku.

W Tatrzańskim Parku Narodowym (rys. 7) można wyróżnić dwa sezony: w miesiącach zimowych (styczeń, luty), kiedy trwa sezon narciarski, oraz w miesiącach letnich, kiedy następuje szczyt sezonu wakacyjnego. Maj, czerwiec i wrzesień to czas, kiedy w Tatry przyjeżdżają wycieczki szkolne, natomiast jesienią wysokie wskaźniki utrzymują się poprzez wyjazdy studenckie oraz wizyty osób, które chcą uniknąć letniego tłoku. Warto dodać, że nawet w ciągu lata w parku może być mało osób. Ruch turystyczny w górach determinują przede wszystkim warunki pogodowe. Tatrzański Park Narodowy zdecydowanie wyróżnia się na tle innych parków pod względem wielkości ruchu turystycznego. Wyjątkowe walory krajobrazowe i klimatyczne, dobrze przygotowana infrastruktura turystyczna, możliwość uprawiania wielu form turystyki, a także symbolika tych gór (np. Giewontu), sprawia, że Tatrzański Park Narodowy jest jednym z najczęściej odwiedzanych obszarów Polski (Buchwał, Fidelus, 2010).

W Wigierskim Parku Narodowym (rys. 7) sezon turystyczny wykazuje podobne cechy jak w Tatrzańskim Parku Narodowym, jednak w tym przypadku wyraźnie widać przewagę miesięcy wiosennych. Szczyt sezonu przypada na okres od maja do sierpnia. W omawianym parku uprawiane są różne formy turystyki wodnej (żeglarstwo, kajakarstwo). Jest on licznie odwiedzany również w tzw. długie weekendy (np. w maju). W miesiącach letnich tradycyjnie następuje szczyt sezonu turystycznego, determinowany przez najkorzystniejsze warunki pogodowe (sezon kąpielowy) (Czarnecki, 2009).

W Biebrzańskim Parku Narodowym (rys. 7) sezon turystyczny przebiega inaczej niż w poprzednio omawianych parkach. Jego szczyt przypada na kwiecień i maj, natomiast sezon pośredni - na miesiące wakacyjne. Warto przypomnieć, że jest to park reprezentujący obszary wodno-błotne, które są siedliskiem życia dla 


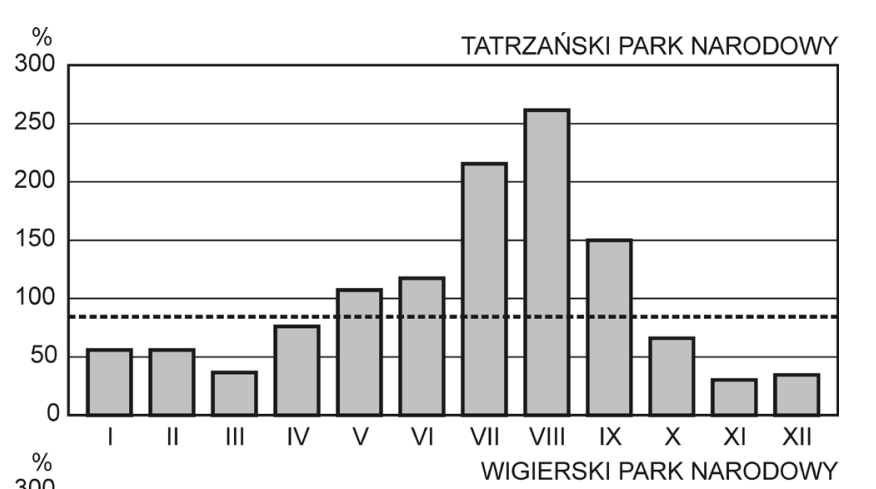

pisze Batyk (2012), w Biebrzańskim Parku Narodowym w znacznym stopniu rozbudowano infrastrukturę turystyczną. Poprawiono stare i wytyczono nowe szlaki, ustawiono schrony, wybudowano wieże i platformy widokowe. Wyznaczono też szlak kajakowy na Biebrzy, wybudowano stanice wodne i wypożyczalnie sprzętu wodnego. Te zabiegi spowodowały wydłużenie sezonu turystycznego oraz wzrost liczby turystów, który można zaobserwować w ostatnich latach.

Szczyt sezonu w Parku Narodowym Bory Tucholskie (rys. 7) przypada na miesiące wakacyjne, aczkolwiek w tym przypadku można wskazać kilka cech charakterystycznych. Nie występuje tutaj sezon pośredni, o którym była mowa w odniesieniu do wcześniej omówionych parków. O atrakcyjności tego miejsca świadczy głównie specyfika walorów środowiska. Jest to obszar o bogatej sieci hydrograficznej oraz o wyjątkowych walorach krajobrazowych. Uprawia się tutaj turystykę piesza, rowerowa, konną oraz wodną. $W$ miesiącach wiosennych (kwiecień-czerwiec) do parku przyjeżdżają grupy szkolne i zorganizowane, natomiast miesiące letnie to czas przyjazdów turystów indywidualnych. Park położony jest blisko miejscowości turystycznych, takich jak Charzykowy i Swornegacie (Szyda, Sokołowski, 2013).

Również inne parki narodowe, których miesięczna frekwencja nie została tutaj przedstawiona ze względu na problemy z monitoringiem, wykazują podobieństwa w ruchu turystycznym. Podobny rozkład mają parki narodowe położone blisko dużych aglomeracji miejskich (Kampinoski, Ojcowski, Wielkopolski). Kampinoski Park Narodowy jest traktowany przez mieszkańców Warszawy jako obszar turystyczno-rekreacyjny. Ruch turystyczny kształtuje się tam inaczej niż we wcześniej omawianych parkach. Szczyt sezonu przypada na miesiące wiosenne (kwiecień-maj). Wiele osób traktuje Kampinoski Park Narodowy jako park podmiejski. Duże natężenie ruchu turystycznego zaobserwowano zwłaszcza w weekendy, kiedy mieszkańcy wybierają się na wycieczki za miasto. W miesiącach wakacyjnych natomiast następuje największy spadek ruchu turystycznego, gdyż wówczas większość mieszkańców udaje się w inne obszary (góry, morze, jeziora) (Dzioban, 2013).

Zjawisko sezonowości można zaobserwować np. w nadmorskich parkach narodowych: Słowińskim i Wolińskim. W obydwu parkach występuje silna koncentracja ruchu turystycznego w miesiącach wakacyjnych (lipiec, sierpień), co jest spowodowane głównie warunkami klimatycznymi (temperatura, nasłonecznienie, długość dnia) oraz okresem wypoczynkowym. Na zwiększenie liczby odwiedzających w miesiącach wakacyjnych może wpływać również fakt, że obydwa parki położone są w pobliżu dużych miejscowości turystyczno-wypoczynkowych - Słowiński Park Naro- 
dowy niedaleko Łeby, a Woliński Park Narodowy nieopodal Świnoujścia. Osoby spędzające urlop w tych miastach, wybierają się do parków na jednodniowe wycieczki. Dużą liczbę turystów odnotowuje się także w czerwcu i we wrześniu. $W$ tych miesiącach odbywa się wiele wyjazdów zorganizowanych: wycieczek szkolnych, wyjazdów biznesowych i zdrowotnych. Najmniej turystów przyjeżdża tam w miesiącach zimowych i wczesnowiosennych (Dusza, 2013; Parzych, 2014).

Szczególne cechy ruchu turystycznego można zauważyć także w przypadku Bieszczadzkiego Parku Narodowego. Szczyt sezonu przypada tam również na miesiące wakacyjne, aczkolwiek najwięcej wejść notuje się w sierpniu i we wrześniu. Najbardziej oblegane przez turystów są szlaki prowadzące na Połoninę Wetlińską oraz na Tarnicę od strony Wołosatego. Sa to jedne z najatrakcyjniejszych obszarów parku pod względem widokowym, kiedy połoniny przybieraja charakterystyczny zielono-złoty kolor. We wrześniu i październiku wśród odwiedzających najwięcej jest grup szkolnych i zorganizowanych oraz studentów (Prędki, 2015).

Po przeanalizowaniu zmian, jakim ulega sezonowość ruchu turystycznego w polskich parkach narodowych, można stwierdzić, że są grupy parków, w których sezon turystyczny wygląda podobnie, np. Park Narodowy Ujście Warty wykazuje bardzo zbliżony rozkład do Biebrzańskiego Parku Narodowego (mała liczba turystów, szczyt sezonu w miesiącach wiosennych, sezon niski w miesiącach jesienno-zimowych, specjalistyczne walory, obszar zalewowy, główni odwiedzający to obserwatorzy ptaków i badacze) (Bałuchto, Chara, Fischbach, Florczak, Kraszewska, 2005). Parki podmiejskie charakteryzują się dużym ruchem turystycznym $\mathrm{w}$ miesiącach wiosennych z maksymalnym spadkiem w okresie wakacyjnym na rzecz parków nadmorskich, górskich i przyjeziornych, które $\mathrm{w}$ tym czasie notują maksymalną liczbę odwiedzających. Można zauważyć, że w niektórych parkach, np. Tatrzańskim, jest więcej niż jeden sezon turystyczny. Sezon wysoki przypada np. na miesiące wakacyjne, ale poza tym widać wyraźnie okres, w którym turyści chętnie odwiedzają dany park, jednak nie tak licznie jak podczas sezonu wysokiego (sezon pośredni). Warto zwrócić uwagę na to, $\mathrm{w}$ jakich porach roku występuje sezon turystyczny. W wielu przypadkach jego szczyt przypada na okres urlopowy (wakacje, „majówka”, ferie) lub świąteczny. Jednak np. w parkach położonych na obszarach wodno-błotnych występowanie sezonu turystycznego wynika wyłącznie z właściwości parku i rodzaju chronionych zasobów. Długość sezonu w parkach narodowych także jest zróżnicowana. W niektórych wysoka frekwencja utrzymuje się przez kilka miesięcy, w innych - jedynie w dwóch miesiącach wakacyjnych. Może być to spowodowane przez warunki klimatyczne, które w konkretnych miesiącach są najkorzystniejsze do odwiedzania danego parku. Widać więc, że zjawisko sezonowości turystycznej w przypadku parków narodowych zaznacza się bardzo wyraźnie i jest zróżnicowane pod wieloma względami, które bardzo często wynikają z właściwości samego parku.

\section{PRZYCZYNY RÓŻNIC W RUCHU TURYSTYCZNYM W PARKACH NARODOWYCH}

Przeprowadzone przez autora analizy wykazały, że jest wiele przyczyn zróżnicowania ruchu turystycznego w polskich parkach narodowych. Mają one odmienny charakter i wynikają z różnych powodów. Jedną z głównych determinant jest położenie geograficzne parku, sprawiające, że posiada on wyjątkową specyfikę, która na tle innych parków narodowych może go wyróżniać, lub też powodować, że nie jest on zbyt popularny. Warto bowiem pamiętać, że charakter obszaru, a co za tym idzie - również jego walory, wpływają na to, jak będzie kształtowała się turystyka w tym miejscu.

Położenie geograficzne warunkuje również dostępność komunikacyjną parku (np. dostęp do miejscowości węzłowych oraz dojazd różnymi środkami transportu), dzięki której w to miejsce może dotrzeć więcej osób niż w przypadku parków położonych peryferyjnie. Dostępność komunikacyjna może być zatem jednym z czynników decydujących o wyborze przez turystę parku, który zechce odwiedzić. Możliwość uprawiania różnych form turystyki i rekreacji jest uzależniona od położenia parku, jego walorów oraz reżimu prowadzonych działań ochronnych (podział parków na strefy ochronne, tj. ścisła, czynną i krajobrazową). Właściwości środowiska powoduja, że na danym obszarze powstaje zagospodarowanie dostosowane do nich tak, by nie generowało szkód. Dla parku narodowego trzeba obrać właściwą strategię turystyczna, dostosowaną do jego specyfiki. Uprawiane są tam formy turystyki, na które pozwala dany obszar i które nie wyrządzą zbyt dużych szkód. Walory parku narodowego mogą odpowiadać większej liczbie osób bądź tylko jego miłośnikom lub specjalistom (jak w przypadku Parku Narodowego Ujście Warty). W takich parkach, jak: Tatrzański, Karkonoski, Pieniński czy Ojcowski, pojedyncze atrakcje lub walory mogą przyciągać rzesze turystów, mimo że są tam również inne warte zobaczenia miejsca. Giewont, Morskie Oko, Śnieżka, Trzy Korony czy Maczuga Herkulesa, ze względu na swoją symbolikę i ogromne znaczenie, bardzo często są obowiązkowymi elementami wypraw wielu turystów, którzy bez odwiedzenia tych miejsc nie opuszczą obszaru parku. Jak widać, jest bardzo wiele przyczyn zróżnicowania ruchu 


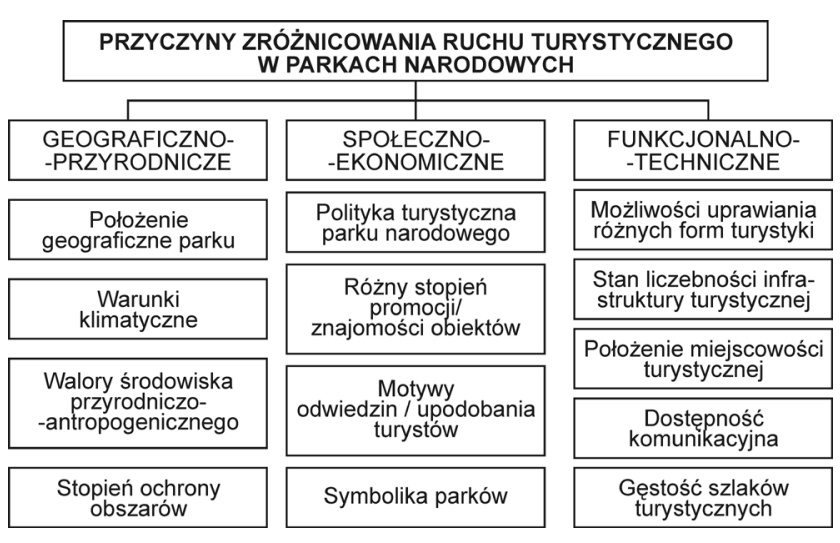

Rysunek 8. Przyczyny zróżnicowania ruchu turystycznego w parkach narodowych

Źródło: opracowanie autora

turystycznego w parkach narodowych (rys. 8). W dużej mierze wynikają one z właściwości konkretnego parku narodowego, ale są również uwarunkowane poprzez inne czynniki.

\section{PODSUMOWANIE}

Przeprowadzone analizy różnych aspektów ruchu turystycznego w polskich parkach narodowych wykazały występowanie wielu elementów, które wpływają na zróżnicowanie liczby turystów odwiedzających te obszary. Należy jednak zwrócić uwagę na fakt, że dana cecha różnicująca nie występuje tylko w odniesieniu do jednego parku. Zazwyczaj jest ona charakterystyczna dla kilku parków, które pod jakimś względem są do siebie podobne lub posiadają zbliżony rozkład ruchu turystycznego. Zaproponowana klasyfikacja parków została opracowana na podstawie analiz różnych aspektów ruchu turystycznego we wszystkich parkach narodowych $w$ Polsce, ich położenia geograficznego oraz danych statystycznych GUS. Cechy, które wyróżniały się najbardziej, decydowały o zaszeregowaniu konkretnego parku do danej grupy. Oczywiście każdy park można by przyporządkować do dwóch kategorii jednocześnie, np. na podstawie informacji pozyskanych na temat Słowińskiego Parku Narodowego można stwierdzić, że pasuje on zarówno do grupy parków wakacyjnych, jak i wycieczkowych, gdyż z analizy ruchu turystycznego w tym parku wynika, że szczyt sezonu przypada tam właśnie na miesiące wakacyjne, ale dużą liczbę turystów odnotowuje się również w miesiącach, w których dominują wyjazdy zorganizowane. Niemniej jednak głównym założeniem podczas dokonywania podziału było uwzględnienie tej cechy, która w danym parku jest najbardziej widoczna i - zdaniem autora - w znacznym stopniu może wpływać na rozkład ruchu turystycznego na tym obszarze.
Opierając się na przeprowadzonych analizach, polskie parki narodowe można podzielić ze względu na:

1. Wielkość ruchu turystycznego (klasyfikacja przeprowadzona na podstawie danych statystycznych udostępnianych przez Główny Urząd Statystyczny): - parki o dużej liczbie turystów (powyżej $1 \mathrm{mln}$ ): Kampinoski, Karkonoski, Wielkopolski, Woliński, Tatrzański;

- parki ośredniej liczbie turystów (od 100 tys. do1 mln): Białowieski, Bieszczadzki, Gór Stołowych, Ojcowski, Pieniński, Roztoczański, Słowiński, Świętokrzyski, Wigierski;

- parki o małej liczbie turystów (do100 tys.): Babiogórski, Biebrzański, Bory Tucholskie, Drawieński, Gorczański, Magurski, Narwiański, Poleski, Ujście Warty.

2. Położenie geograficzne (strefa krajobrazowa):

- parki nadmorskie: Słowiński, Woliński;

- parki na obszarach jeziorno-leśnych: Białowieski, Bory Tucholskie, Drawieński, Kampinoski, Roztoczański, Wielkopolski, Wigierski;

- parki na obszarach wodno-błotnych lub w dolinach rzek: Biebrzański, Narwiański, Poleski, Ujście Warty;

- parki wyżynne: Ojcowski, Poleski;

- parki górskie: Babiogórski, Bieszczadzki, Gorczański, Gór Stołowych, Karkonoski, Magurski, Pieniński, Świętokrzyski.

3. Dostępność komunikacyjną (klasyfikacja przeprowadzona na podstawie analizy dostępności parków narodowych, dokonanej przy użyciu narzędzi Geoportal i Google Maps oraz wykonanych map odległości parków od aglomeracji miejskiej):

- dobrze skomunikowane - podmiejskie: Kampinoski, Ojcowski, Świętokrzyski, Wielkopolski;

- dobrze skomunikowane - peryferyjne: Białowieski, Biebrzański, Bory Tucholskie, Gorczański, Gór Stołowych, Karkonoski, Narwiański, Pieniński, Roztoczański, Słowiński, Tatrzański, Ujście Warty, Woliński;

- słabo skomunikowane - peryferyjne: Babiogórski, Bieszczadzki, Drawieński, Magurski, Poleski, Wigierski.

4. Sezonowość ruchu turystycznego (klasyfikacja dokonana na podstawie przeprowadzonych analiz rozkładu ruchu turystycznego w parkach narodowych. Podstawą zaszeregowania były miesiące, w których dany park odwiedziło najwięcej osób oraz które najwyraźniej wskazywały na sezon turystyczny. W przypadku parków kilkusezonowych o ich zaszeregowaniu zdecydowały także ich specjalistyczne walory, które w konkretnej porze roku powoduja że park jest odwiedzany właśnie ze względu na nie): - wakacyjne (największa liczba turystów w lipcu i sierpniu): Bieszczadzki, Gorczański, Karkonoski, Pieniński, Słowiński, Wigierski, Woliński; 
- wycieczkowe (znaczna liczba turystów w maju, czerwcu i wrześniu): Babiogórski, Białowieski, Bory Tucholskie, Drawieński, Gór Stołowych, Kampinoski, Magurski, Ojcowski, Świętokrzyski, Wielkopolski;

- kilkusezonowe: Biebrzański, Narwiański, Poleski, Roztoczański, Tatrzański, Ujście Warty.

5. Możliwość uprawiania różnych form turystyki (w celu opracowania klasyfikacji posłużono się danymi liczbowymi GUS (długość szlaków, infrastruktura turystyczna) oraz wzięto pod uwagę różne cechy parków narodowych, które zdaniem autora wpływają na możliwość uprawiania turystyki w parku, np. położenie geograficzne, ukształtowanie powierzchni i rodzaj chronionych zasobów środowiska, reżim ochrony, polityka ochronna i turystyczna parku, rodzaje szlaków turystycznych):

- multifunkcyjne turystycznie (więcej niż trzy formy): Babiogórski, Bieszczadzki, Gorczański, Gór Stołowych, Karkonoski, Pieniński, Tatrzański, Wigierski, Woliński;

- polifunkcyjne turystycznie (dwie-trzy formy): Biebrzański, Bory Tucholskie, Drawieński, Kampinoski, Magurski, Roztoczański, Wielkopolski,

- monofunkcyjne turystycznie (jedna dominująca forma): Białowieski, Narwiański, Ojcowski, Poleski, Słowiński, Świętokrzyski, Ujście Warty.

Dokonywanie podziałów oraz klasyfikacji parków narodowych jest sprawą dyskusyjną ze względu na mnogość cech tych obszarów oraz ich zróżnicowanie. Kryteria i kategorie, do których zaszeregowano parki, dobrano tak, aby po odnalezieniu danego parku we wszystkich grupach, można było jak najlepiej określić jego charakter oraz wskazać najważniejsze cechy ruchu turystycznego na tym obszarze.

\section{BIBLIOGRAFIA}

Bałuchto, B., Chara, P., Fischbach, K., Florczak, K., Kraszewska, A. (2005). Ruch turystyczny w Parku Narodowym Ujście Warty. W: R. Machowski, M. Rzętała (red.), Z badań nad wptywem antropopresji na środowisko (s. 9-18). Sosnowiec: Uniwersytet Śląski.

Batyk, I. (2012). Zagospodarowanie turystyczne obszarów chronionych na przykładzie Biebrzańskiego Parku Narodowego. Infrastruktura i Ekologia Terenów Wiejskich, 2 (III), 207-216.

Biebrzański Park Narodowy (2019). Pobrane z: http://biebrza.org.pl (27.06.2019).

Błażejczyk, K., Kunert, A. (2011). Bioklimatyczne uwarunkowania rekreacji i turystyki w Polsce. Warszawa: PAN.

Buchwał, A., Fidelus, J. (2010). Monitoring ruchu turystycznego przy użyciu czujników ruchu na przykładzie Tatrzańskiego i Babiogórskiego Parku Narodowego. W: Z. Krzan (red.), Przyroda Tatrzańskiego Parku Narodowego a człowiek (s. 45-54). Zakopane: Wydawnictwo TPN.
Czarnecki, K. (2009). Atrakcyjność turystyczna i ruch turystyczny w parkach narodowych województwa podlaskiego. Zeszyty naukowe SGGW, 73, 165-172.

Dusza, E. (2013). Zmienność natężenia ruchu turystycznego na obszarze Wolińskiego Parku Narodowego. Problemy Ekologii Krajobrazu, XXXIV, 275-279.

Dzioban, K. (2013). Wielkość ruchu turystycznego w Kampinoskim Parku Narodowym. Studia i Materiaty CEPL, 15, 90-96.

Fidelus, J. (2008). Rola ruchu turystycznego w przekształcaniu ścieżek i dróg turystycznych na obszarze Tatrzańskiego Parku Narodowego. Prace Geograficzne, 120, 19-29.

Gałązka, M. (2009). Turystyka zrównoważona w parkach narodowych w opinii turystów. Studia i Materiały CEPL, 4, 123-130.

Geoportal (2019). Pobrane z: http://geoportal.gov.pl (16.06.2019).

Głuchowski, R., Nawrocka-Grześkowiak, U. (2013). Skutki turystyki na terenach objętych ochroną na przykładzie Drawieńskiego Parku Narodowego. Zarzadzanie Ochrona Przyrody w Lasach, 7, 336-346.

Google Maps (2019). Pobrane z: http://maps.google.pl (24.06.2019).

Graja-Zwolińska, S., Spychała, A. (2014). Monitoring ruchu turystycznego w parkach narodowych. Barometr Regionalny, $12(4), 171-177$.

Hibner, J. (2013). Struktura ruchu turystycznego w polskich górskich parkach narodowych należących do sieci „Człowiek i Biosfera". W: P. Krąż, J. Hibner, J. Koj (red.), Wspótczesne problemy i kierunki badawcze w geografii (s. 73-88). Kraków: Instytut Geografii i Gospodarki Przestrzennej UJ.

Hibner, J. (2014). Monitoring ruchu turystycznego w rejonie Kasprowego Wierchu - metody i problemy badawcze. Wspótczesne Problemy i Kierunki Badawcze w Geografii, 2, 33-47.

Jastrzębski, C. (2009). Ruch turystyczny w Świętokrzyskim Parku Narodowym. Studia i Materiaty CEPL, 4, 199-205.

Kajala, L. (red.) (2007). Visitor monitoring in nature areas: A manual based on experiences from the Nordic and Baltic Countries. Stockholm: Swedish Environmental Protection Agency.

Klimska, U., Swianiewicz, P. (2005). Społeczne i polityczne zróżnicowanie aglomeracji w Polsce - waniliowe centrum, mozaika przedmieść. Prace i Studia Geograficzne, 35, 45-70.

Koźmiński, C., Michalska, B. (2016). Sezonowość i zmienność ruchu turystycznego w Polsce. Zeszyty Naukowe Uniwersytetu Szczecińskiego, 3, 9-23. DOI: https://doi.org/10.18276/ ept.2016.3.35-01

Krakowiak, B. (2000). Charakterystyka ruchu turystycznego w parkach narodowych Karpat Zachodnich - typy funkcjonalne parków. Turyzm, 1, 5-37.

Kruczek, Z., Przybyło-Kisielewska, K. (2019). Ruch turystyczny w parkach narodowych i konsekwencje nadmiernej frekwencji odwiedzających. W: M. Nocoń, T. Pasierbek, J. Sobczuk, B. Walas (red.), Parki narodowe $i$ ich otoczenie społeczno-gospodarcze. Skazani na dialog (s. 160-171). Sucha Beskidzka: WSTiE.

Lawin, M. (2000). Ruch turystyczny w Magurskim Parku Narodowym i jego otulinie. Turyzm, 10 (2), 31-56.

Liszewski, S. (2009). Przestrzeń turystyczna parków narodowych w Polsce. W: B. Domański, W. Kurek (red.), Gospodarka i Przestrzeń (s. 187-201). Kraków: Instytut Geografii i Gospodarki Przestrzennej UJ.

Mazurczak, M. (2009). Realizacja założeń ekoturystyki na obszarze Parku Narodowego Ujście Warty. Studia i Materiaty CEPL, 4, 206-211.

Ochrona Środowiska 2008 (2008). Warszawa: Główny Urząd Statystyczny.

Ochrona Środowiska 2018 (2018). Warszawa: Główny Urząd Statystyczny.

Partyka, J. (2002). Użytkowanie turystyczne parków narodowych. Ojców: Ojcowski Park Narodowy. 
Partyka, J. (2010a). Ruch turystyczny w polskich parkach narodowych. Folia Turistica, 22, 9-25.

Partyka, J. (2010b). Udostępnianie turystyczne parków narodowych w Polsce a krajobraz. Prace Komisji Krajobrazu Kulturowego, 14, 252-263.

Parzych, K. (2014). Wybrane cechy ruchu turystycznego w Słowińskim Parku Narodowym na podstawie badań ankietowych. Journal of Education, Healt and Sport, 4 (13), 246-256.

Prędki, R. (2015). Ruch turystyczny w Bieszczadzkim Parku Narodowym w latach 2012-2014. Roczniki Bieszczadzkie, 23, 367-385.

Rogowski, M. (2017). System monitoringu ruchu turystycznego (SMrt) w Parku Narodowym Gór Stołowych - założenia i wybrane wyniki. Studia i Materiaty CEPL, 52, 158-165.

Rogowski, M. (2018). System Monitoringu ruchu turystycznego (SMrt) w Parku Narodowym Gór Stołowych dla potrzeb badań przestrzeni turystycznej. Prace i Studia Geograficzne, 63.3, 153-172.

Semczuk, M. (2012). Ruch turystyczny w Gorczańskim Parku Narodowym. Ochrona Beskidów Zachodnich, 4, 98-110.

Smoleński, M. (2006). Turystyka w parkach narodowych. W: R. Ziółkowski (red.), Praktyczne aspekty rozwoju turystyki i rekreacji na obszarach przyrodniczo cennych. Białystok: Wydawnictwo Politechniki Białostockiej.
Stasiak, A. (1997). Turystyka w parkach narodowych - obszary konfliktów, Turyzm, 7 (2), 5-24.

Stasiak, A., Śledzińska, J., Włodarczyk, B. (red.) (2014). Szlaki turystyczne. Od pomystu do realizacji. Warszawa: Wydawnictwo PTTK „Kraj”.

Szyda, B., Sokołowski, D. (2013). Turystyczne użytkowanie Parku Narodowego Bory Tucholskie. Studia i Materiaty CEPL, 37, 305-312.

Ustawa z dnia 16 kwietnia 2004 r. o ochronie przyrody. Dz.U. 2004, nr 92, poz. 880.

Walas, B. (red.) (2019). Model optymalizacji funkcjonowania parków narodowych w Polsce w otoczeniu społeczno-gospodarczym. Sucha Beskidzka: WSTiE.

Wieniawska-Raj, B. (2007). Dynamika ruchu turystycznego w Karkonoskim Parku Narodowym. Opera Corcontica, 44, 593-602.

Włodarczyk, B. (1993). Funkcja turystyczna Świętokrzyskiego Parku Narodowego w świetle badań ruchu turystycznego. Turyzm, 1, 5-29.

Artykuł wpłyną: 2 sierpnia $2019 \mathrm{r}$. Zaakceptowano do druku: 15 czerwca $2020 \mathrm{r}$. 